UDC 57.084.1 + 577.21 + 573.6.086.83: 577.21+602

\title{
Nicotiana cavicola as a host for production of recombinant proteins by Agrobacterium-mediated transient gene expression.
}

\author{
Y. R. Sindarovska1 ${ }^{1}$, Z. M. Olevinskaya ${ }^{2}$, O. A. Demchenko², N. Y. Spivak², N. V. Kuchuk ${ }^{1}$ \\ ${ }^{1}$ Institute of Cell Biology and Genetic Engineering, NAS of Ukraine \\ 148, Akademika Zabolotnogo Str., Kyiv, Ukraine, 03143 \\ ${ }^{2}$ D. K. Zabolotny Institute of Microbiology and Virology, NAS of Ukraine \\ 154, Academika Zabolotnoho Str., Kyiv, Ukraine, 03143 \\ sindarovskaya@ukr.net
}

\begin{abstract}
Aim. To analyze a novel plant species as a host for obtaining recombinant proteins via transient gene expression. Methods. Agrobacterium-mediated transient gene expression, protein analysis, statistical data processing. Results. $N$. cavicola plants demonstrate good biotechnological characteristics; they are susceptible to agrobacterial infection and plant viruses. Green fluorescent protein (GFP) and human interferon alpha were produced in $N$. cavicola after transient gene expression using two different vector systems. The level of recombinant proteins depended on the gene and the system used. GFP content reached $6.0 \%$ and $12.6 \% \mathrm{TSP}(0.44 \mathrm{mg} / \mathrm{g}$ FW). The interferon antiviral activity of the leaf extracts was $840 \mathrm{IU} / \mathrm{g} \mathrm{FW}$ and $1710 \mathrm{IU} / \mathrm{g} \mathrm{FW}$. Conclusion. Here we propose $N$. cavicola species as a novel host for obtaining recombinant proteins which can be used as an alternative to the $N$. benthamiana host.

Ke y w o r d s: Nicotiana cavicola, Agrobacterium-mediated transient expression, recombinant proteins, human interferon alpha, GFP
\end{abstract}

\section{Introduction}

The plant transient expression (TE) of transgenes is a fast, reliable and simple method that extensively used for fundamental physiological research and applied biotechnological purposes [1-3]. Potentially TE can be used for rapid production of pharmaceutically valuable proteins, including antibodies [4-7]. Rapid production of antibodies or vaccine proteins is preferable in the treatment of advanced cancer diseases or in case of season epidemic diseases. In case of TE, the transgenes are not integrated into plant genome thus avoiding the position effects and providing considerably increased levels of recombinant proteins [8].

The protocols for Agrobacterium-mediated TE of transgenes in Nicotiana benthamiana plants are well developed and widely applicable. $N$. benthamiana demonstrates high sus-

(C) 2019 Y. R. Sindarovska et al.; Published by the Institute of Molecular Biology and Genetics, NAS of Ukraine on behalf of Biopolymers and Cell. This is an Open Access article distributed under the terms of the Creative Commons Attribution License (http://creativecommons.org/licenses/by/4.0/), which permits unrestricted reuse, distribution, and reproduction in any medium, provided the original work is properly cited 
ceptibility to agrobacterial and viral infections $[9,10]$, and is considered as a model host for TE. However, common utilization of one species gives some limitations and hides the advantages of other species, e.g. increased recombinant protein levels or better biotechnological characteristics. Earlier, it was proved the important role of host species for successful production of recombinant proteins [11].

Here we describe a new host for TE of transgenes, namely Nicotiana cavicola. This species can be easily infiltrated, it is susceptible to agrobacterial transfection, assures transgene expression from various expression cassettes (different vector systems), and produces recombinant proteins in large amounts. The final levels of green fluorescent protein (GFP) and human interferon alpha $2 \mathrm{~b}$ obtained in $N$. cavicola plants were comparable to or surpassing the corresponding levels obtained in $N$. benthamiana plants.

\section{Materials and Methods}

Plant growth conditions. Nicotiana spp. seeds were obtained from "National Germplasm Bank of World Flora of the Institute of Cell Biology and Genetic Engineering" (Kyiv, Ukraine). Seeds were germinated either in unsterile conditions (commercial soil) or in aseptic conditions on MS agar medium [12] after surface sterilization [13]. Plants grew in greenhouse conditions: 16-hour light day at $22-28^{\circ} \mathrm{C}, 3000-4000$ lux. Leaves of 6-8-week old plants were used for the experiments.

Agrobacterial strains and genetic constructions. Vector constructions were harbored into Agrobacterium tumefaciens GV3101 strain. The used plasmids (pICH5290, pICH7410, pICH10570, pICH10881,
pICH17311, pICH6692) were obtained for scientific purposes from Icon Genetics $\mathrm{GmbH}$ (Halle, Germany) and described in [14, 15]. The plasmid pCB125 was described in [16]. The sequence coding for the human interferon alpha $2 b$ was fused with calreticulin signal from $N$. plumbaginifolia for the protein targeting to intracellular space [15].

Two different vector systems used in the experiments were described in the earlier publication [11]. One of them represents a simple vector construction where a gene of interest was driven by the $35 \mathrm{~S} \mathrm{CaMV}$ promoter (named herein as 35S-system).

Another vector system (named herein as recombinase vector (Rec) system) includes combination of viral genome elements and binary plasmid of $A$. tumefaciens. This vector system requires simultaneous introduction of three vector modules into the same cell for in planta assembly of the RNA replicon [11, 14].

Bacteria growing and infiltration procedure. Growth and preparation of agrobacteria for the infiltration were performed as described $[11,15]$. Infiltration was carried out according to Schob et al. [17] with minor modifications [15]. Mixed bacterial suspension (100 $\mu 1 /$ sample) was injected at the same leaf position to exclude sample variability [18]. There were two control groups of plants: the first group was infiltrated with the buffer only; the second one was infiltrated just with the agrobacterium clone which harbored the vector construction with the $p 19$ gene (a suppressor of post-transcriptional gene silencing). All experiments were done in 7-10 replications.

Extraction of total soluble proteins. Plant material was collected on the $4^{\text {th }}$ day post infiltration (dpi) if $35 \mathrm{~S}$ expression system was 
used or on the $16^{\text {th }}$ dpi if the recombinase expression system was used.

GFP extraction procedure: $0.1-0.2 \mathrm{~g}$ of fresh plant material was ground on ice in 1.5 $\mathrm{ml}$ tubes in $500 \mu 1$ of cold sodium phosphate buffer, and debris was precipitated by centrifugation at the top speed. The supernatant was transferred into clean tube. A new portion of buffer $(500 \mu \mathrm{l})$ was added to the sediment and procedure was repeated. The total supernatant was used for the next analysis.

Interferon extraction procedure: plant leaf tissue was collected, weighted and ground on ice with a mortar and a pestle in one volume of cold Tris-base buffer. Grinded leaves were transferred in $1.5 \mathrm{ml}$ tubes and the debris was precipitated by two-round top speed centrifugation to clarify a supernatant. The supernatant was used for the next analysis.

GFP extraction buffer: $50 \mathrm{mM} \mathrm{Na} 2 \mathrm{HPO}_{4} /$ $\mathrm{NaH}_{2} \mathrm{PO}_{4}, \mathrm{pH}$ 7.0. Interferon extraction Trisbase buffer was described in [15].

Measurement of the concentration of total soluble proteins. The quantity of total soluble proteins (TSP) was measured according to Bradford's method [19] using bovine serum albumin as a standard.

GFP assay. The presence of recombinant GFP in leaf tissues was determined and its quantity was calculated as described earlier [11]. The percentage of GFP per TSP was calculated as well.

Assessment of antiviral activity of interferon. The protective antiviral activity of experimental extracts was demonstrated in titration assay described in [15]. The dilution of sample where $50 \%$ of the cells survived after vesicular stomatitis virus infection was determined as the titer of interferon. Based on titers of standard interferon alpha $2 b$ the activity of extracts was estimated in International Units (IU).

Statistical data processing. For statistical data manipulations, standard deviation (SD) and Student's test were used. Bars on diagrams demonstrate standard deviation [20].

\section{Results and Discussion}

Nicotiana cavicola, an Australian species of tobacco is classified together with $N$. benthamiana in the same subgenus. Several studies revealed a high sensitivity of $N$. cavicola to a wide range of plant viruses $[21,22]$. This feature is distinctive also for $N$. benthamiana, which suggests that $N$. cavicola along with $N$. benthamiana may be used for the heterologous protein production via transient expression (TE) if the gene is located in a viral based vector system.

To investigate a biological potential of $N$. cavicola, two mentioned species were compared for several parameters: growth in greenhouse conditions, plant biomass, easiness of infiltration procedure, possibility of Agrobacteriummediated TE of transgenes and the production of desired proteins.

Growth in greenhouse conditions. The mature seeds of $N$. cavicola sprouted on the $4^{\text {th }}-6^{\text {th }}$ days similarly to $N$. benthamiana ones, and we did not observe any difference in the plant germination rate between the surface sterilized or non-sterilized seeds. Subsequently, the nonsterilized seeds were germinated directly in a commercial soil mixture. We found that $N$. cavicola can be used for TE experiments at the age of 6-8 weeks but before appearance of flowers [11]. The 6-8 weeks old $N$. benthamiana plants were often used for TE as well [23, 
24]. The N. cavicola plants demonstrate efficient growth in greenhouse and their fully expanded leaves are bigger than those of $N$. benthamiana ones grown under the same conditions (Fig. 1).

Plant biomass and infiltration procedure. Total biomass weights of $N$. cavicola and $N$. benthamiana plants available for the protein production were compared. As shown in the Table 1, one fully expanded leaf of $N$. cavico$l a$ weighs more than that of $N$. benthamiana. The difference was significant $(\mathrm{P}<0.001)$. $N$. benthamiana demonstrates the best production of recombinant proteins in five upper mature leaves [11], whereas only three upper mature leaves can be used in N. cavicola. Thus, there was no difference between the species in the total leaf biomass useful for protein production.

$N$. cavicola leaves are nicely infiltrated by bacterial suspension without lateral vein restriction. Simplicity of leaf infiltration is typical for young $N$. benthamiana plants.

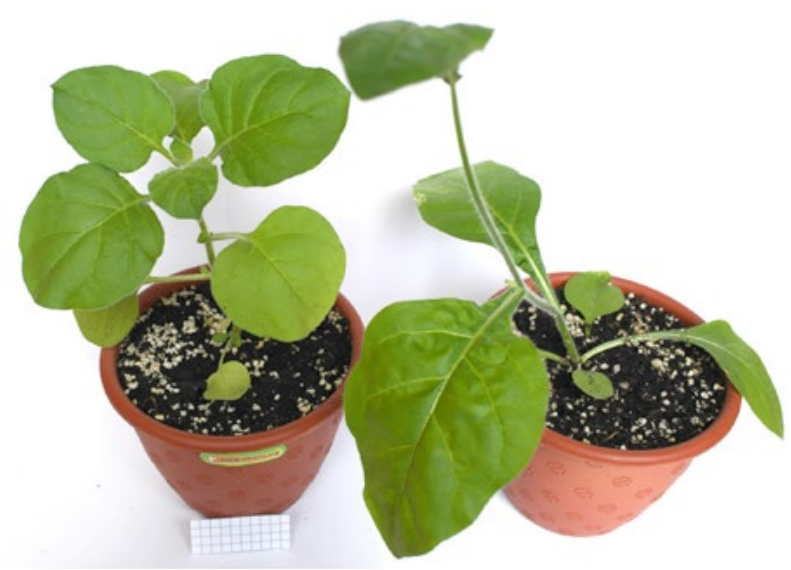

Fig. 1. Plants of $N$. cavicola (right) and $N$. benthamiana (left) grown in greenhouse ( 8 weeks old). Paper scale is $5 \mathrm{~cm}$.
Table 1. Comparison of biomass characteristics of two Nicotiana species grown under greenhouse conditions

\begin{tabular}{l|c|c|c}
\hline Plant species & $\begin{array}{c}\text { Mean leaf } \\
\text { weight, } \\
\mathrm{g} \pm \text { standard } \\
\text { deviation (SD) }\end{array}$ & $\begin{array}{c}\text { Number } \\
\text { of leaves } \\
\text { used for } \\
\text { TE }\end{array}$ & $\begin{array}{c}\text { Sum biomass } \\
\text { of leaves used } \\
\text { for TE, } \mathrm{g} \pm \mathrm{SD}\end{array}$ \\
\hline N. cavicola & $1.182 \pm 0.359$ & 3 & $3.5 \pm 0.88$ \\
\hline N. benthamiana & $0.534 \pm 0.137$ & 5 & $2.67 \pm 0.3$ \\
\hline
\end{tabular}

Recombinant protein production: Green Fluorescent Protein (GFP). Vital reporter protein, GFP, was used for the assessment of recombinant protein production in $N$. cavicola. Two vector systems carrying the $g f p$ gene were used for the experiments. One vector includes the $g f p$ gene driven by $35 \mathrm{~S}$ CaMV promoter, whereas another system, a recombinase vector (Rec) system [8, 14], includes two pro-vectors and the $g f p$ gene appears under the viral subgenomic promoter after the recombination event.

Green fluorescence was detected under shot-wave UV-light within infiltrated areas that confirmed the presence of heterologous GFP

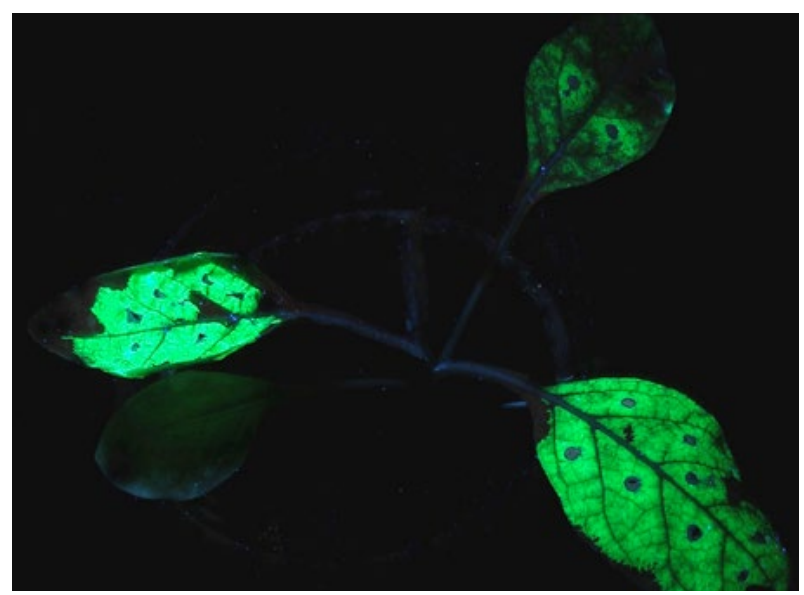

Fig. 2. $N$. cavicola plants producing recombinant protein GFP, view under UV light. Green colour leaf areas demonstrate GFP accumulation (clear areas in black-white variant). 
(Fig. 2). The viral suppressor of gene silencing p19 was used to increase the heterologous protein production $[25,26]$.

Total soluble proteins (TSP) were extracted from the infiltrated leaf areas and the contents of GFP and TSP were calculated as described.

The GFP content in $N$. cavicola leaves reached $6.0 \pm 1.51 \%$ TSP when $35 \mathrm{~S}$ system was used. In $N$. benthamiana leaves the GFP level reached $3.84 \pm 1.31 \%$ TSP (Fig. 3). The difference between the means was significant $(\mathrm{P}<0.05)$. The data were compared with the data obtained earlier for other Nicotiana spp. [11] and it was noted that the percentage of GFP in $N$. cavicola was the highest. In general, a higher percentage of heterologous protein will invest in facilitation of the next purification procedure.

The GFP content calculated per a plant biomass unit was $0.440 \pm 0.140 \mathrm{mg} / \mathrm{g}$ fresh weight (FW) in N. cavicola and $0.312 \pm 0.075 \mathrm{mg} / \mathrm{g} \mathrm{FW}$ in $N$. benthamiana. The difference was not

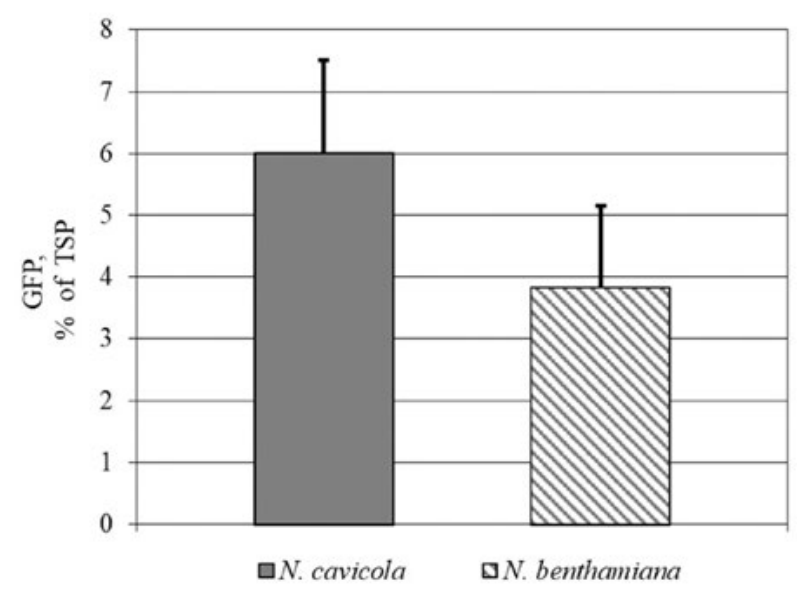

Fig. 3. Comparison of GFP content in plant extracts (35S system). The difference between means was significant $(\mathrm{P}<0.05)$. Bars mean SD. statistically significant. The average amount of TSP in $N$. benthamiana tissues was higher than that in $N$. cavicola: $9.43 \pm 3.07 \mathrm{mg} / \mathrm{g} \mathrm{FW}$ and $7.36 \pm 2.01 \mathrm{mg} / \mathrm{g} \mathrm{FW}$, respectively.

Then GFP content was measured after applying the Rec system. Usage of this system resulted in an increase of GFP percentage compared to $35 \mathrm{~S}$ system but the amount of GFP per gram of fresh weight was similar to $35 \mathrm{~S}$ system: $12.59 \pm 6.48 \%$ TSP (or $0.438 \pm 0.218 \mathrm{mg} / \mathrm{g}$ FW) in $N$. cavicola and $16.2 \pm 5.7 \%$ TSP (or $0.365 \pm 0.122 \mathrm{mg} / \mathrm{g} \mathrm{FW}$ ) in $N$. benthamiana (Fig. 4). Further analysis revealed that the TSP level in experimental leaves reduced: $3.86 \pm 1.32 \mathrm{mg} / \mathrm{g}$ FW in $N$. cavicola and $2.26 \pm 1.04 \mathrm{mg} / \mathrm{g} \mathrm{FW}$ in $N$. benthamiana. The possible explanation is senescence of leaves and diminution of proteins during the experimental period: the maximal level of recombinant protein accumulation after using the Rec system is reached on the $14^{\text {th }}-16^{\text {th }}$ days post infiltration (dpi), whereas the $35 \mathrm{~S}$ system al-

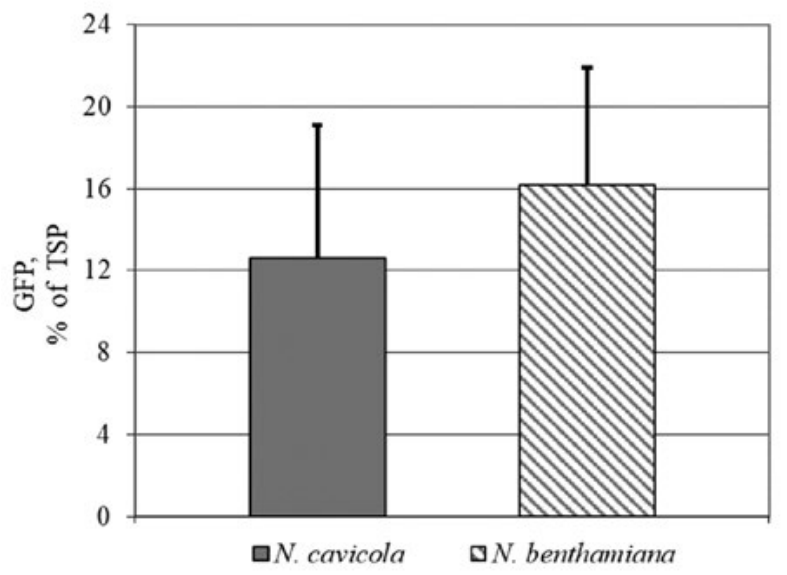

Fig. 4. Comparison of GFP content in plant extracts (the Rec system). The difference between means was not significant $(\mathrm{P}>0.05)$. Bars mean SD. 
lows collection of leaves on the $4^{\text {th }}$ dpi. An increased GFP percentage after applying the Rec system may ensure advantages for the following protein purification steps. In the previous paper [11] it was shown that not all Nicotiana species were sensitive to the Rec system and some of them did not accumulate GFP in measurable quantities.

The obtained data proved that $N$. cavicola is susceptible to agrobacterial infection, and T-DNA is transferred efficiently in the plant cells. Additionally, N. cavicola demonstrates visible sensitivity to different expression systems. This confirms that $N$. cavicola is a perspective host for obtaining heterologous proteins via the Agrobacterium-mediated transient gene expression.

Human interferon (INF) alpha $2 b$ production. To check if the tested host can produce the proteins not as stable as GFP, human interferon $\alpha 2 b$ was chosen for the next experiments. To reach the aim, the identical expression systems (the $35 \mathrm{~S}$ system and Rec system) were used but the $g f p$ gene was replaced by the inf gene. The experimental conditions were the same except for the extraction procedure. In the course of experiment, it was confirmed the presence of antiviral activity in the extracts prepared from the infiltrated leaves. This can be regarded as a proof of the bioactive heterologous interferon production in $N$. cavicola cells.

If the $35 \mathrm{~S}$ system was used, the average antiviral activity detected in the $N$. cavicola leaf extracts was $844 \pm 302$ International Units (IU)/g FW (variation range 770-1570 IU/g FW), and the average antiviral activity detected in the $N$. benthamiana leaf extracts was $281 \pm 105 \mathrm{IU} / \mathrm{g}$ FW (variation range 170-370 IU/g FW) (Fig. 5). The INF production in $N$. cavicola was about
3 times higher than in $N$. benthamiana. The difference between the means was significant $(\mathrm{P}<0.01)$. These data agree with the data shown for the GFP production.

Further, antiviral activity was measured in the leaf extracts obtained after using the Rec system. In this case antiviral activity of extracts increased if compared with the data shown for the $35 \mathrm{~S}$ system: the average activity was $1714 \pm 855 \mathrm{IU} / \mathrm{g} \mathrm{FW}$ (variation range 800-2400 IU/g FW).

In general, the total amount of INF was less than the total amount of GFP obtained in the same manner. The possible explanation of such results is a different degradation rate of the various proteins in plant cells. GFP conformation provides its high proteolytic stability [27] whereas native human INF is attacked by plant proteases more frequently. Moreover, optimal conditions for accumulation of recombinant proteins can vary significantly.

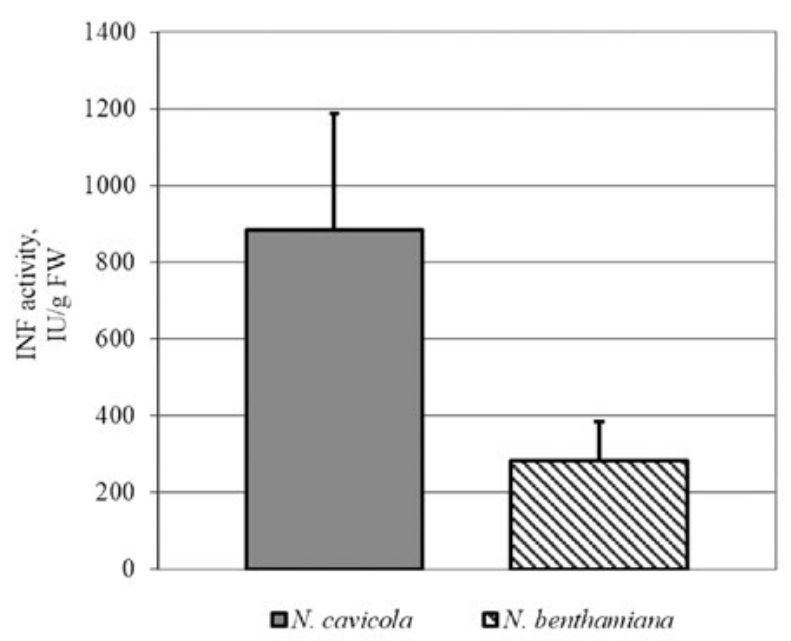

Fig. 5. Comparison of interferon activity in plant extracts from two Nicotiana species (the $35 \mathrm{~S}$ system). The difference between means was significant $(\mathrm{P}<0.01)$. Bars mean SD. 


\section{Conclusions}

A detailed inspection of characteristics essential for efficient production of recombinant proteins showed that the Nicotiana cavicola leaves are suitable for infiltration, the species is susceptible to agrobacterial transfection and assures the transgene expression from various expression cassettes. Two recombinant proteins, namely reporter protein GFP and human interferon alpha $2 \mathrm{~b}$, were successfully produced in the $N$. cavicola plants after transient gene expression. The final GFP and INF levels differed, mainly because of different protein properties. The INF level was not as high as the GFP level and some other plant system can produce higher quantities of recombinant INF, therefore Nicotiana cavicola still looks promising species for the recombinant protein production via transient gene expression.

\section{Acknowledgements}

The authors thank Icon Genetics GmbH (Halle, Germany) and Dr. I.M. Gerasymenko (Institute of Cell Biology and Genetic Engineering) for kindly donated plasmids carrying the genes of interest. The authors thank Bogomoletz Institute of Physiology for providing the fluorescence spectrophotometer for GFP measurements.

\section{Funding}

This work was supported by grant from NAS of Ukraine (No. 0110U006061).

\section{REFERENCES}

1. Sainsbury F, Lomonossoff GP. Transient expressions of synthetic biology in plants. Curr Opin Plant Biol. 2014;19:1-7.

2. Sheludko $Y V$. Agrobacterium-mediated transient expression as an approach to production of recom- binant proteins in plants. Recent Pat Biotechnol. 2008;2(3):198-208.

3. Yamamoto T, Hoshikawa K, Ezura K, Okazawa R, Fujita S, Takaoka M, Mason HS, Ezura H, Miura K. Improvement of the transient expression system for production of recombinant proteins in plants. Sci Rep. 2018;8(1):4755.

4. Komarova TV, Baschieri S, Donini M, Marusic C, Benvenuto E, Dorokhov YL. Transient expression systems for plant-derived biopharmaceuticals. Expert Rev Vaccines. 2010;9(8):859-76.

5. Paul M, Ma JK. Plant-made pharmaceuticals: leading products and production platforms. Biotechnol Appl Biochem. 2011;58(1):58-67.

6. Thuenemann EC, Lenzi P, Love AJ, Taliansky M, Bécares $M$, Zuñiga S, Enjuanes L, Zahmanova $G G$, Minkov IN, Matić S, Noris E, Meyers A, Hattingh A, Rybicki EP, Kiselev OI, Ravin NV, Eldarov MA, Skryabin KG, Lomonossoff GP. The use of transient expression systems for the rapid production of viruslike particles in plants. Curr Pharm Des. 2013; 19(31):5564-73.

7. Nandi S, Kwong AT, Holtz BR, Erwin RL, Marcel S, $M c D o n a l d ~ K A$. Techno-economic analysis of a transient plant-based platform for monoclonal antibody production. MAbs. 2016/Dec;8(8):1456-1466. Erratum in: MAbs. 2017/Mar;9(2):391.

8. Marillonnet S, Giritch A, Gils M, Kandzia R, Klimyuk $V$, Gleba $Y$. In planta engineering of viral RNA replicons: efficient assembly by recombination of DNA modules delivered by Agrobacterium. Proc Natl Acad Sci U S A. 2004; 101(18):6852-7..

9. Yang SJ, Carter SA, Cole AB, Cheng NH, Nelson RS. A natural variant of a host RNA-dependent RNA polymerase is associated with increased susceptibility to viruses by Nicotiana benthamiana. Proc Natl Acad Sci U S A. 2004;101(16):6297-302.

10. Goodin MM, Zaitlin D, Naidu RA, Lommel SA. Nicotiana benthamiana: its history and future as a model for plant-pathogen interactions. Mol Plant Microbe Interact. 2008;21(8):1015-26.

11. Sheludko YV, Sindarovska YR, Gerasymenko IM, Bannikova MA, Kuchuk NV. Comparison of several Nicotiana species as hosts for high-scale Agrobac- 
Nicotiana cavicola as a host for production of recombinant proteins by Agrobacterium-mediated transient gene expression.

terium-mediated transient expression. Biotechnol Bioeng. 2007;96(3):608-14.

12. Murashige T, Skoog F. A revised medium for rapid growth and bioassays with tobacco tissue culture. Physiol Plantarum. 1962; 15(3):473-97.

13. Sindarovska YR, Gerasymenko IM, Sheludko YV, Komarnytskyy IK, Bannikova MA, Kuchuk NV. Transgenic plants regenerated from hairy roots of Nicotiana benthamiana: a promising host for transient expression of foreign proteins. Tsitol Genet. 2005;39(6):9-14.

14. Marillonnet $S$, Thoeringer C, Kandzia R, Klimyuk $V$, Gleba $Y$. Systemic Agrobacterium tumefaciensmediated transfection of viral replicons for efficient transient expression in plants. Nat Biotechnol. 2005;23(6):718-23.

15. Sindarovska YR, Gerasymenko IM, Sheludko YV, Olevinskaja ZM, Spivak NY, Kuchuk NV. Production of human interferon alfa $2 \mathrm{~b}$ in plants of Nicotiana excelsior by Agrobacterium-mediated transient expression. Cytol Genet. 2010; 44(5):313-6.

16. Gerasymenko IM, Lypova NM, Sakhno LA, Shcherbak NL, Sindarovska YR, Bannikova MA, Kuchuk NV. Obtain-ing and analysis of tobacco, lettuce and rape plants transformed with human interferon alfa $2 \mathrm{~b}$ gene. Factors of experimental evolution of organisms. 2009; 7:274-9.

17. Schöb H, Kunz C, Meins F Jr. Silencing of transgenes introduced into leaves by agroinfiltration: a simple, rapid method for investigating sequence requirements for gene silencing. Mol Gen Genet. 1997;256(5):581-5.

18. Buyel JF, Fischer R. Predictive models for transient protein expression in tobacco (Nicotiana tabacum L.) can optimize process time, yield, and downstream costs. Biotechnol Bioeng. 2012; 109(10):2575-88.

19. Bradford $M M$. A rapid and sensitive method for the quantitation of microgram quantities of protein utilizing the principle of protein-dye binding. Anal Biochem. 1976;72:248-54.

20. Lakin FG. Biometry. Moscow: "Vysshaya Shkola", 1990;350p.

21. Van Dijk P, van der Meer FA, Piron PG. Accession of Australian Nicotiana species suitable as indicator hosts in the diagnosis of plant virus diseases. $\mathrm{Ne}$ ther J Plant Pathol. 1987; 93(2):73-85.

22. Wylie SJ, Zhang C, Long V, Roossinck MJ, Koh SH, Jones $M G$, Iqbal S, Li H. Differential responses to virus challenge of laboratory and wild accessions of australian species of nicotiana, and comparative analysis of RDR1 gene sequences. PLoS One. 2015;10(3): 0121787.

23. Conley AJ, Zhu H, Le LC, Jevnikar AM, Lee BH, Brandle JE, Menassa R. Recombinant protein production in a variety of Nicotiana hosts: a comparative analysis. Plant Biotechnol J. 2011;9(4):434-44.

24. Shamloul M, Trusa J, Mett V, Yusibov V. Optimization and utilization of Agrobacterium-mediated transient protein production in Nicotiana. $J$ Vis Exp. 2014;(86).

25. Dhillon T, Chiera JM, Lindbo JA, Finer JJ. Quantitative evaluation of six different viral suppressors of silencing using image analysis of transient GFP expression. Plant Cell Rep. 2009;28(4):639-47.

26. Shamekova M, Mendoza MR, Hsieh Y-C, Lindbo J, Omarov RT, Scholthof HB. Tombusvirus-based vector systems to permit over-expression of genes or that serve as sensors of antiviral RNA silencing in plants. Virology. 2014; 452-453:159-65.

27. Cubitt AB, Heim R, Adams SR, Boyd AE, Gross LA, Tsien $R Y$. Understanding, improving and using green fluorescent proteins. Trends Biochem Sci. 1995;20(11):448-55.

\section{Nicotiana cavicola як господар для виробництва біофармацевтичних препаратів у рослинах шляхом Agrobacterium-опосередкованої транзіснтної експресії генів}

Я. Р. Сіндаровська, 3. М. Олевинська, О. А. Демченко, М. Я. Співак, М. В. Кучук

Мета. Аналізувати новий вид рослин як господаря для отримання рекомбінантних білків шляхом транзієнтної експресії генів. Методи. Agrobacterium-опосередкована транзієнтна експресія генів, аналіз білків, статистична обробка даних. Результати. Рослини N. cavicola демонструють гарні біотехнологічні характеристики, i вони сприйнятливі до агробактеріальної інфекції та до рослинних вірусів. В результаті транзієнтної експресії 
генів з використанням двох різних векторних систем в N. cavicola напрацьовувався зелений флуоресцентний білок (GFP) і людський інтерферон альфа. Рівень рекомбінантних білків залежав від використаного гена i системи. Вміст GFP сягав 6,0 \% і 12,6 \% СРБ (0,44 мг/г СВ). Противірусна активність інтерферону з екстрактів листя становила $840 \mathrm{MO} / \Gamma$ CВ і $1710 \mathrm{MO} / г \mathrm{CB}$. Висновки. У даній статті ми пропонуємо вид $N$. cavicola в якості нового господаря для отримання рекомбінантних білків, який може бути використаний як альтернатива господарю $N$. benthamiana .

Кл юч о в і с лов а: Nicotiana cavicola, Agrobacteriumопосередкована транзієнтна експресія, рекомбінантні білки, людський інтерферон альфа, GFP.

\section{Nicotiana cavicola как хозяин для производства биофармацевтических препаратов в растениях путём Agrobacterium-опосредованной транзиентной экспрессии генов}

Я. Р. Синдаровская, 3. М. Олевинская, А. А. Демченко, Н. Я. Спивак, Н. В. Кучук

Цель. Анализировать новый вид растений в качестве хозяина для получения рекомбинантных белков посредством транзиентной экспрессии генов. Методы.
Agrobacterium-опосредованная транзиентная экспрессия генов, анализ белков, статистическая обработка данных. Результаты. Растения N. cavicola демонстрируют хорошие биотехнологические характеристики, и они восприимчивы к агробактериальной инфекции и к растительным вирусам. В результате транзиентной экспрессии генов с использованием двух различных векторных систем в $N$. cavicola нарабатывался зеленый флуоресцентный белок (GFP) и человеческий интерферон альфа. Уровень рекомбинантных белков зависел от используемого гена и системы. Содержание GFP достигало 6,0 \% и 12,6 \% СРБ (0,44 мг/г СВ). Противовирусная активность интерферона из экстрактов листьев составляла 840 МЕ/Г СВ и $1710 \mathrm{ME} / \Gamma$ СВ. Выводы. В данной статье мы предлагаем вид $N$. cavicola в качестве нового хозяина для получения рекомбинантных белков, который может быть использован как альтернатива хозяину $N$. benthamiana.

Ключевые слова: Nicotiana cavicola, Agrobacterium-опосредованная транзиентная экспрессия, рекомбинантные белки, человеческий интерферон альфа, GFP.

Received 06.06.2019 